\title{
VILNIAUS DAUGIABUČIŲ GYVENAMUৃJŲ NAMŲ STATYBOS RAIDOS TENDENCIJOS NEPRIKLAUSOMYBĖS LAIKOTARPIU
}

\author{
Gintaras Čaikauskas \\ Architektūros katedra, Vilniaus Gedimino technikos universitetas, \\ Pylimo g. 26/Trakug. 1, LT-01132 Vilnius, Lietuva. El.paštas gintaras.caikauskas@architekturoslinija.lt \\ Itteikta 20080626
}

Santrauka. Architektūriniu aspektu analizuojamos Vilniaus daugiabučių gyvenamųjų namų statybos raidos tendencijos Nepriklausomybès laikotarpiu, lyginant jas su ikikariniu bei sovietmečio periodais, nagrinèjamos išliekamosios meninės vertės formavimosi prielaidos. Nagrinėjamos naujausių laikų realizacijos, jų specifika ir ypatybès, atskleidžiami esminiai konceptualiai skirtingų sprendimų bruožai.

Reikšminiai žodžiai: investicijų modelis, miesto infrastruktūra, juridinè bazè, detalieji planai, teritorijų urbanizavimas, pastatų modernizavimas.

\section{İvadas}

Viena iš seniausių statinių tipologinių grupių - gyvenamieji namai - tiesiogiai atspindi visuomenès raidos bruožus, iš kartos ị kartą perteikia civilizacijos pasiekimus. Šių objektų architektūrinès stilistikos raida suformavo ir Lietuvos kultūros paveldą, pokario urbanistiniai daugiabučių masyvai, susiję su šalies industrijos plètra, reikšmingai išplète miestų ribas.

Kiekvienas istorinis laikotarpis pasižymi tam tikrais charakteringais bruožais. Visas pasaulis žavisi Vilniaus Senamiesčio - viduramžiško miesto - romantiška dvasia, jaukiomis erdvèmis, siauromis, vingriomis gatvelèmis, pastatų siluetų dinamika, nuolatine detalių kaita, tapybiškomis panoramomis, netikètai atsiveriančiomis daugiaplanemis perspektyvomis. Ankšti kiemai, sudètingos eismo sąlygos, saulès šviesos ir šviežio oro trūkumas - visa tai gyventojams ir nekilnojamojo turto vertintojams ar pirkèjams nesukelia didesnių buitinių, verslo, psichologinių ar kitokių problemų. „Puikiu investicijų skatinimo pavyzdžiu reikètų laikyti Vilniaus Senamiesčio atgaivinimo programą. Rezultatai pranoksta lūkesčius" (Naujokaitis 2002). Nors ši aplinka ir nebuvo formuojama vadovaujantis kanonizuotais mokslo pagrindais ar profesionaliais projektavimo normatyvais, bet ji visuomet buvo ir tebèra pati patraukliausia visų laikų investuotojams. Šios sèkmès priežastys slypi daug giliau, jos susijusios su prigimtinèmis žmogaus savybèmis. „Senamiesčio plano struktūros užuomazgos anaiptol nebuvo kažin kokių atsitiktinumų, ideologizuotų kieno nors įnorių ar estetinių užgaidų rezultatas. Tai racionaliai pažinta visos vietos gamtinio karkaso kokybė, pragmatiškai įvertinta ir tikslingai panaudota, - taip reikètų charakterizuoti pirminę ir tolesnę Senamiesčio raidą nulèmusią kompozicinès sandaros motyvaciją “ (Buivydas 2006). Meninè aplinkos verte, susiklosčiusi metams bègant, nulemta gyvenamosios terpès harmonijos su unikalia Vilniaus gamta, akcentuota bažnyčių bokštų vertikalemis, ICOMOS organizacijoje pagrịstai ivertinta tarptautiniu mastu. Vilniaus Senamiesčiui suteikus pasaulio kultūros vertybès statusą, sustiprinus jo valstybinę apsaugą, atsirado specialių juridinių svertų, taip pat finansinès prielaidos restauruoti pastatus, tarp jų ir gyvenamuosius namus, gerinti aplinkos kokybę.

Gyventojų itin pamėgti Vilniaus Naujamiestyje esantys vèlesniụjų architektūros stilių pastatai, o ypač tie, kurių architektūroje jaučiama eklektikos laikotarpio stilistikos ịtaka, kurių butai jaukūs, žmogiškojo mastelio, su aukštomis lubomis, stoglangiais apšviestomis išraiškingomis laiptinèmis, gausiu išorès ir vidaus dekoru ir įdomia polichromija. Dažnai tai pastatai, esantys netoli Senamiesčio, tačiau patalpos juose yra gerokai erdvesnès negu viduramžiais statytų pastatų, jie stovi šalia platesnių gatvių. Tiems, kurie nori jaustis tikrais miestiečiais, jie yra ypač priimtini daugeliu atžvilgių: patogi, prestižinè padètis miesto centro atžvilgiu, išraiškinga architektūra, geras vidinių erdvių išdèstymas, tradiciné, patikima statybos technologija, patvarios medžiagos. Pagrindinis trūkumas - šiuolaikinès automobilių 
laikymo ir pastatymo problemos (anuometinio gyvenimo būdo sąlygomis tokių reikalavimų nekelta).

Pokariniai sovietmečio gyvenamųjų kvartalų mikrorajonai, priešingai iki tol vyravusioms susiklosčiusioms tradicijoms ir meistrų patirtimi pagrịstai statybai, buvo realizuoti laikantis galiojusių moksliškai nustatytų ir tyrimais pagrịstų valstybès aprobuotų visuomenès sveikatos apsaugos, statybinès fizikos ir moderniu laisvojo planavimo koncepcijų. „Tokią urbanistinio projektavimo manierą, be Centro rekomenduojamu „pavyzdinių“ generalinių planų, lèmè ir populiarumo apogèjų pasiekusios „Atènų chartijos“ postulatais bei nuostatomis persmelkta pati projektavimo metodika, o ypač direktyvūs, besąlygiškai ịpareigojantys anuometiniai urbanistiniai, architektūriniai ir statybiniai normatyvai - „SNIP“ („Stroitelnyje normy i pravila“). Griežti kanonai palikdavo mažai laisvès kūrybiškesniems sumanymams" (Vanagas 2003). Nors tuo metu šie sprendimai atspindèjo pažangiausias urbanistines gyvenamosios aplinkos formavimo idèjas, tačiau buvo realizuoti pagal socializmo ekonomikos diktuojamas technologines galimybes ir iki šiol tebèra nesibaigiančiu diskusijų objektas.

Esminis ekonominis skirtumas tarp sovietmečiu bei šiais laikais planuojamų ir statomų daugiabučių gyvenamųjų namų masyvų iš esmès yra pagrịstas visiškai kitokiu investicijų modeliu. Socialistinès statybos vykdavo panaudojant valstybines arba iš dalies kooperatines lèšas (koncentruotas kooperatyvo narių asmenines lèšas). Tai praktiškai eliminavo žmogaus kaip individo asmeninès valios ir iniciatyvos apraiškas, meninio suvokimo, realios ittakos vykdomiems projektavimo ir statybos sprendimams galimybes. Projektuotojai vadovavosi valstybès patvirtintais normatyvais ir taisyklemis, kuriuose būdavo reglamentuojami visi pagrindiniai reikalavimai: būstų dydžiai, atstumai tarp gyvenamųju pastatų, vaikų darželių, žaidimo aikštelių poreikis, mokyklu vietos, prekybos centrai, buitiniai kompleksai, automobilių saugyklos ar jų aikštelès, želdynų plotai ir pan. Toks visiškai centralizuotas planavimas buvo įmanomas tik esant bendrai žemès nuosavybei, investuojamoms visuomeninėms lèšoms ir privataus pelno siekiu nesuinteresuotoms valstybinès nusavybès rangovinems organizacijoms. Antra vertus, patvirtinti valstybiniai sprendimai būdavo ịgyvendinami, nauja gyvenamoji aplinka nelikdavo be socialinių ir infrastruktūros objektų.

\section{Daugiabučių gyvenamųjų namų statyba Vilniuje atkūrus Nepriklausomybę}

Lietuvai atgavus valstybinę nepriklausomybę ir visuomeniniuose santykiuose atsikūrus rinkos ekonomikos sąlygoms, daugiabučių gyvenamųjų namų statyba visoje šalyje, o ypač sostineje Vilniuje tapo itin pelningu verslu. Investuotojai pradejo laisvų sklypų paiešką ir, pasinaudodami pereinamojo laikotarpio ekonomikos silpnumu bei finansinès infliacijos sąlygomis, masinị jų supirkimą. Pasibaigus sovietmečio sąstingiui miesto vystymo urbanistiniai dokumentai nebuvo pakankamai parengti intensyviai statybai, išliko nesuformuota ir neišvystyta miesto inžinerinio aprūpinimo sistema, transporto infrastruktūra, tebebuvo paviršutiniška ir siaura juridine projektavimo reikalavimų bazè. Agresyvus, tačiau nebrandus privataus kapitalo veikimas Lietuvoje sukūrè daug abejotinos vertès nekilnojamojo turto rinkos objektų, ir šio proceso pabaigos dar nematyti.

Varomoji šiuolaikinès gyvenamosios aplinkos formavimo jèga yra finansinis privačių asmenų suinteresuotumas, kuris dar nepakankamai reglamentuotas viešojo ar valstybinio intereso gynimo įstatymais. Gana plačiai įsigalèjus privačiai žemès nuosavybei, daugejjant investicijų, kurias sudaro asmeninès lèšos, glaudžiai susijusios su komercinių bankų paskolomis ir jų palūkanų grąžinimo normomis bei terminais, gyvenamasis plotas (kitaip tariant, nekilnojamasis turtas) tapo vienu iš didžiausių šalies ekonomikos sektorių, pasižyminčių visomis prekių mainų sferai būdingomis savybèmis, privalumais ir trūkumais.

Nepriklausomybės laikotarpiu Vilniuje susiformavo kelios pagrindinès daugiabučiu gyvenamųjų namų statybos tendencijos.

\subsection{Pastatai - senamiesčio intarpai}

Tiek sovietmečiu, tiek dabartiniais laikais užpildomos istoriškai susiklosčiusio Senamiesčio perimetrinio užstatymo spragos. Jos atsirado po bombardavimų karo metu, veliau - vadovaujantis socializmo idejomis („siekiant likviduoti buržuazini palikimą“), kartais neapdairiai ir neatsakingai pašalinus istorinių pastatų griuvėsius. Nesibaigiančios diskusijos lydi kiekvieną naują intarpą Senamiestyje. Itin jautrus miesto istorinis kontekstas ir paviršutiniška architektų, projektuojančiu pastatus Senamiesčio audinyje, patirtis visuomenei, o ypač paveldo apsaugos institucijų atstovams visuomet kèlè didelị susirūpinimą, kuris dažniausiai pasireiškia kaip naujų projektų atmetimo reakcija. Sovietmečiu ir vèliau, nepriklausomybès laikotarpiu, realizuoti ne visuomet sèkmingi architektūriniai naujos statybos ban- 


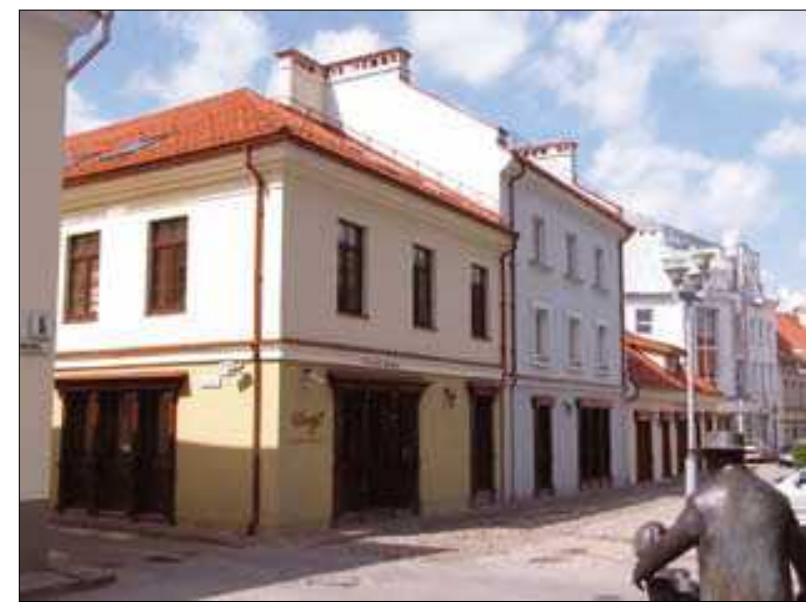

1 pav. Daugiabučių gyvenamujų namų kvartalas su administracinemis, prekybos ir paslaugu patalpomis Ašmenos, Dysnos ir Mèsinių g. (archit. A. Gvildys, A. Gvildienè, D. Bikmanaite)

Fig. 1. Blocks of flats with the office, commercial and service premises in Ašmena, Dysna, Mèsinè st. Arch. A. Gvildys, A. Gvildienè, D. Bikmanaitè

dymai nepajègé ịrodyti, kad nauja, vertinga meninè kokybė įmanoma ir susiklosčiusioje aplinkoje. „Lietuvos sąjūdžio laikotarpiu buvo kritikuojamas Senamiesčio kvartalų kompleksinis regeneravimas. Kritikuojamas greičiausiai todèl, kad dalị kvartalų projektų rengè ne restauratoriai, o to meto „Komprojekto“ architektai“ (Glemža 2002). Verslo interesai nepaisè konceptualiai neapibrèžtos architektūrinès padèties nekilnojamojo turto vystymo sferoje ir, ieškodami lengviausios išeities, siekdami sukurti naujus plotus nekilnojamajam turtui, sudare prielaidas kompromisinès (dar kartais vadinamos atstatomaja - imitacine) stilistikos precedentu atsiradimui, kurie dažniausiai tebèra taikomi projektuojant naujus pastatus Senamiestyje. Ekspertai ir vertintojai dažnai abejoja tokios architektūrinès tendencijos vasavertiškumu. „Atstatymas yra skolinys, citata, patekusi i svetimą tekstą ir praradusi bet kokią gyvos minties galią, yra pavojingas architektūros ir miestų statybos paveldo autentiškumui, paprastam kasdienio gyvenimo daiktų paveldui, originaliai šiuolaikinei architektūrai“" (Markevičienè 1999).

Kai kurie pastatai ar jų grupés Senamiestyje atstatyti vadovaujantis archeologiniais tyrimais, istorinemis studijomis, daugiau ar mažiau archyvuose išlikusia ikonografine medžiaga arba ją laisvai interpretuojant (1 pav.), tačiau visais atvejais buvo vengiama naujesnès kokybès paryškinimo kaip nereikalingos kliūties aprobuojant projektinę dokumentaciją kultūros paveldo institucijose (2 pav.). „Nekyla abejonių, kad buvo išpildytas reikalavimas atstatytą objektą suvokti kaip naują statybą.

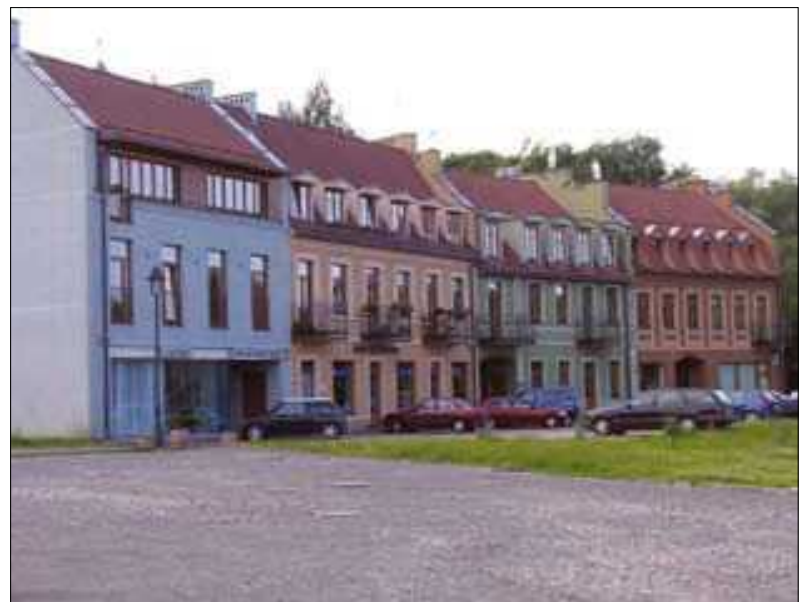

2 pav. Gyvenamujų namų Tymo kvartale Maironio g. fragmentas (archit. H. Štaudè, J. Leskevičius)

Fig. 2. Fragment of Tymo residential quarter in Maironis st. Arch. H. Štaudè, J. Leskevičius

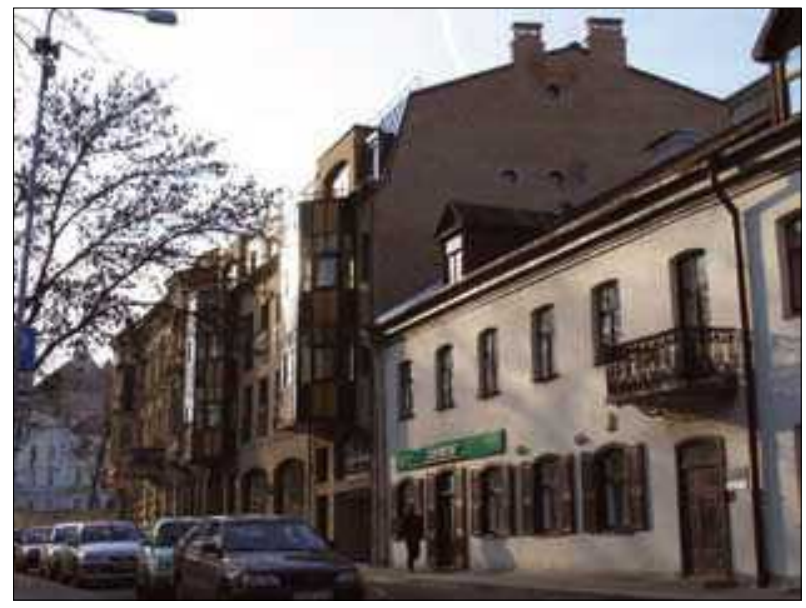

3 pav. Daugiabutis gyvenamasis namas su jistaigomis L. Stuokos-Gucevičiaus g. (archit. A. Songaila)

Fig. 3. Block of flats with offices in L. Stuoka-Gucevičius st. Arch. A. Songaila

Galiausiai yra kur kas didesnè problema - neturime kultūros vertybių atsatymo koncepcijos. Ši problema vis iš naujo kils tvarkant ir saugant istorinius miestus" (Riaubienè 2001). „Nors architektūros šiuolaikiškumas, traktuojamas kaip laikotarpio architektūros tendencijų ir statybos laiko atspindejjimas, yra svarbus reikalavimas, keliamas naujai architektūrai istorinejje aplinkoje, tačiau tai nèra svarbus jos vertinimo kriterijus: tiek labiausiai pavykusiais, tiek nepavykusiais ịvardyti pastatai yra šiuolaikinès architektūros" (Navickienè 2006). Naujos architektūros projektinių sprendimų 


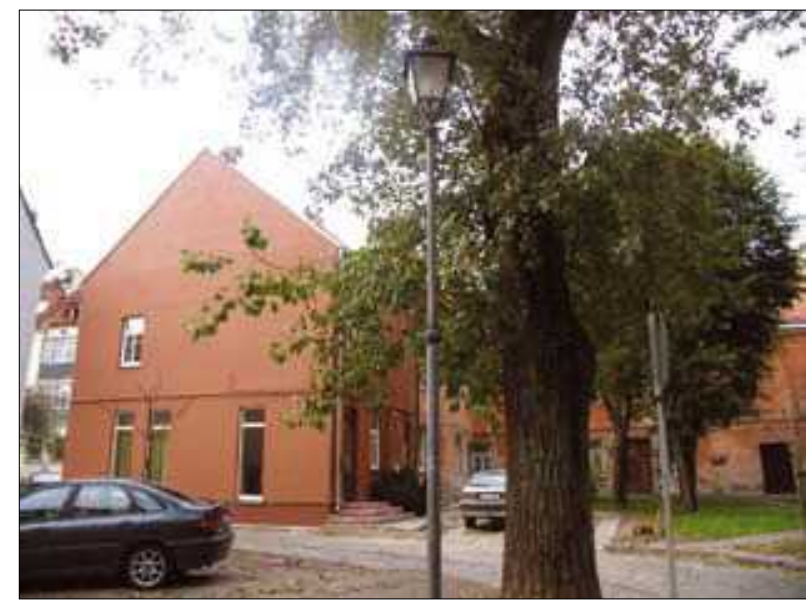

4 pav. Daugiabučio gyvenamojo namo priestatas su parduotuve Šiaulių g. (archit. G. Čaikauskas, P. Petkus)

Fig. 4. Extension of the block of flats with a shop in Šiauliai st. Arch. G. Čaikauskas, P. Petkus

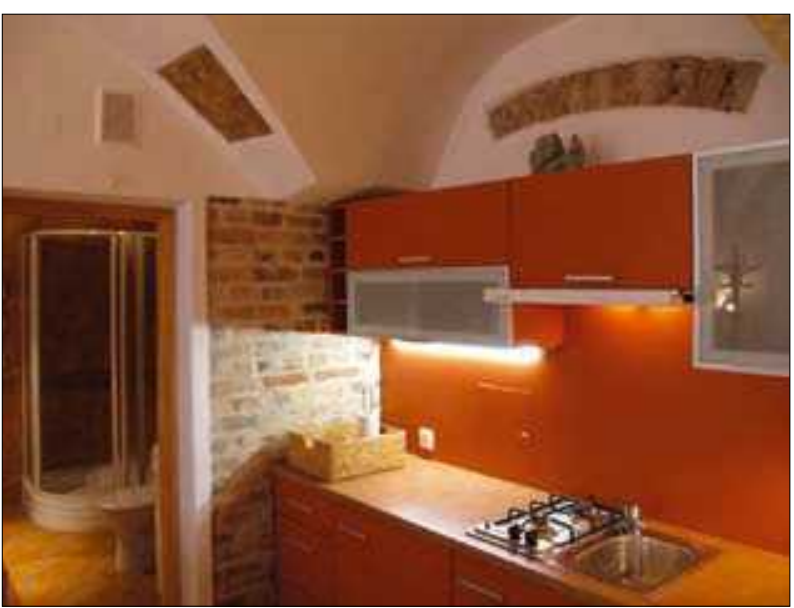

5 pav. Buto senamiestyje interjeras

(archit. G. Čaikauskas, D. Čaikauskienè)

Fig. 5. Interior of a flat in the old city.

Arch. G. Čaikauskas, D. Čaikauskienè

kritika oficialiose instancijose retai būdavo konceptualiai motyvuota, dažniausiai kuriant ir tvirtinant projektus buvo vadovaujamasi subjektyviu konteksto ir istorinio palikimo traktavimu, tiesiog vizualiai ir emociškai sprendžiant, kaip vienokie ar kitokie architektūriniai sprendimai atrodys šalia išlikusių pastatų (3 pav.). „Didžiausiu trukdžiu gauti gerą architektūros kokybę kai kurie ekspertai laiko sudètingą derinimo procesą <...> " (Navickienè 2006). Projektų Senamiestyje derinimo tvarka buvo labai politizuota, galiojo ịvairių ekspertų tarybų svarstymo metodika, sudètinga projektinès dokumentacijos aprobavimo sistema, kiekvieną būsimą pastato sprendimą peržiūrèdavo asmeniškai net pats miesto meras. Nepaisant derinančių instancijų pastangų, procedūros kartais duodavo atvirkštinị efektą. „Lyginant tarybiniu ir nepriklausomos Lietuvos laikotarpiu paskelbtoje literatūroje pateiktą naujos architektūros Lietuvos miestų istorinèje aplinkoje vertinimą, matyti, kad esminių pokyčių vertinant ją nèra, taikyti analogiški vertinimo kriterijai. Ir tarybiniu laikotarpiu, ir atkūrus nepriklausomybę, teigiamai vertinti šiuolaikinès aukštos meninès vertès architektūros, darnaus santykio su aplinka pastatai ir neigiamai vertinti urbanistiniai istorinès aplinkos pokyčiai, stalininès architektūros, nederančios su istorine aplinka architektūros ir tipinių projektų pastatai“ (Navickienė 2006). Kai kuriuose realizuotuose objektuose buvo atsargiai bandoma ieškoti aktualesnio, subjektyvaus istorinès architektūrinès išraiškos individualizavimo, tačiau galutinis rezultatas nedaug nutolo nuo istorinių formų konteksto ir meninių parafrazių ịvaizdžio (4 pav.). Drąsesni naujos kokybès sprendimai sukurti tik rekonstruojamuose būstų interjeruose ( 5 pav.), kuriuose praktiškai jau neįmanomas restauravimo procesas. „Palankiai kūrybos terpei formuoti reikia spręsti architektų ir paveldo apsaugos specialistų konfliktą dèl architektūros kūrybos prioritetų. Glaudus paveldo apsaugos specialistų ir projektuotojų bendradarbiavimas, pagrịstas žiniomis ir kompetencija, o ne draudimai ir griežta kontrolè skatina kontekstiškus kūrybos rezultatus" (Navickienè 2004).

\subsection{Kvartalu formavimas Naujamiestyje}

Kai kuriose netoli nuo miesto centro esančiose Vilniaus dalyse, taip pat ir Naujamiestyje, iki karo nebuvo visiškai užbaigti formuoti kvartalai. Sovietmečiu jie išliko nesuformuoti. Nepriklausomybès laikotarpiu šios teritorijos, suvokus itin didelę jų vertę, buvo nuosekliai užstatomos. Naujieji tūriai priklausomai nuo subjektyvios autorių pozicijos ir taikomų stilistinių metodų buvo formuojami kontekstualiomis priemonemis, siekiant išlaikyti būdingą nepertraukiamo perimetro užstatymo morfotipą. Taip buvo realizuoti Naujamiesčio kvartalai Teatro gatveje (6 pav.), Tauro kalno kaimynystejje tarp Čiurlionio ir Sierakausko gatvių. Pasirinkta architektūros išraiška, iš dalies reaguojanti ị šalia esančių pastatų istorinis stilius, tęsè postmodernizmo tendencijas. Gretimybèms būdinga eklektikos periodo architektūra šiuolaikinėmis, moderniomis išraiškos priemonèmis, pasitelkus polichromiją, buvo perfrazuota ir originaliai interpretuota daugiabučiame name su komercinèmis patalpomis Sierakausko gatveje (7 pav.). „Nors fasadas konstrukciniais sumetimais plokščias, apdailintas 


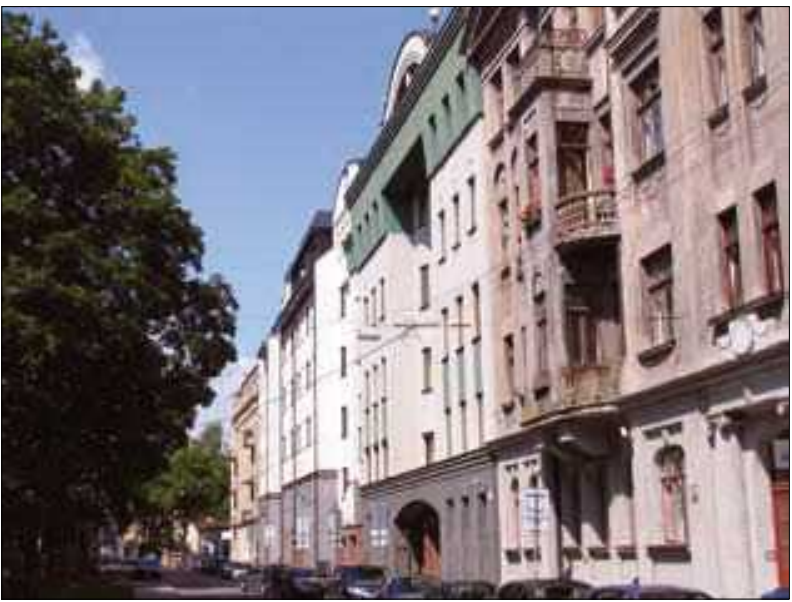

6 pav. Daugiabučių gyvenamujų namų kompleksas su komercinèmis patalpomis Teatro g. (archit. A. Blotnys) Fig. 6. Block of flats with the commercial premises in Teatras st. Arch. A. Blotnys

ivairiaspalviu tinku, jis vizualiai sluoksniuojasi, tampa reljefiškas" (Navickienè 2000).

Plataus atgarsio visuomeneje ir teigiamo specialistų i̇vertinimo sulaukè Krivių g. Užupyje, Senamiesčio prieigose, statomas ne perimetrinio, bet atskirų tūrių, taškinio užstatymo morfotipo gyvenamasis kvartalas (8 pav. ). „Pagal Užupio užstatymo charakterị ir namų grupès kompozicija tokia, kad būtų išsaugotas ryšys su gamta, svarbia gatvès išklotinių kompozicijai“ (Leitanaitè 2002). Šiuose pavyzdžiuose naujausios architektūros tendencijos buvo kontekstualizuotos tiek urbanistinèje erdveje, tiek architektūriniuose sprendimuose, aplinkos mastelio pojūtis bei modernios detalès susiklosčiusioje aplinkoje sukūrè naujos kokybès apraiškas.

\subsection{Daugiabučių namų statyba sovietmečio gyvenamosiose teritorijose}

Daugelį metų egzistuojančiuose sovietmečio statybos gyvenamuosiuose mikrorajonuose, kurie pagal tuometinius projektus realizuoti kaip užbaigtos urbanistinès kompozicijos, nepriklausomybès laikais juridiškai buvo formuojami dar neužstatyti plotai arba išperkamos tarp daugiabučių išlikusios dèl ịvairiausių priežasčių neiškeldintos praejusio šimtmečio priemiesčių sodybos. Išanalizavus realias statybos galimybes, tokios teritorijos privatizuojamos laikantis įstatyminių nuosavybès grąžinimo nuostatų arba tiesiog nuperkamos jau esančios privačios valdos. Rengiami lokalūs detalieji planai, kurie viešųjų svarstymų procedūros metu dažniausiai susilaukia gretimose teritorijose gyvenančių senbuvių pasipriešinimo ir tvirtinami tik privalomomis teismu

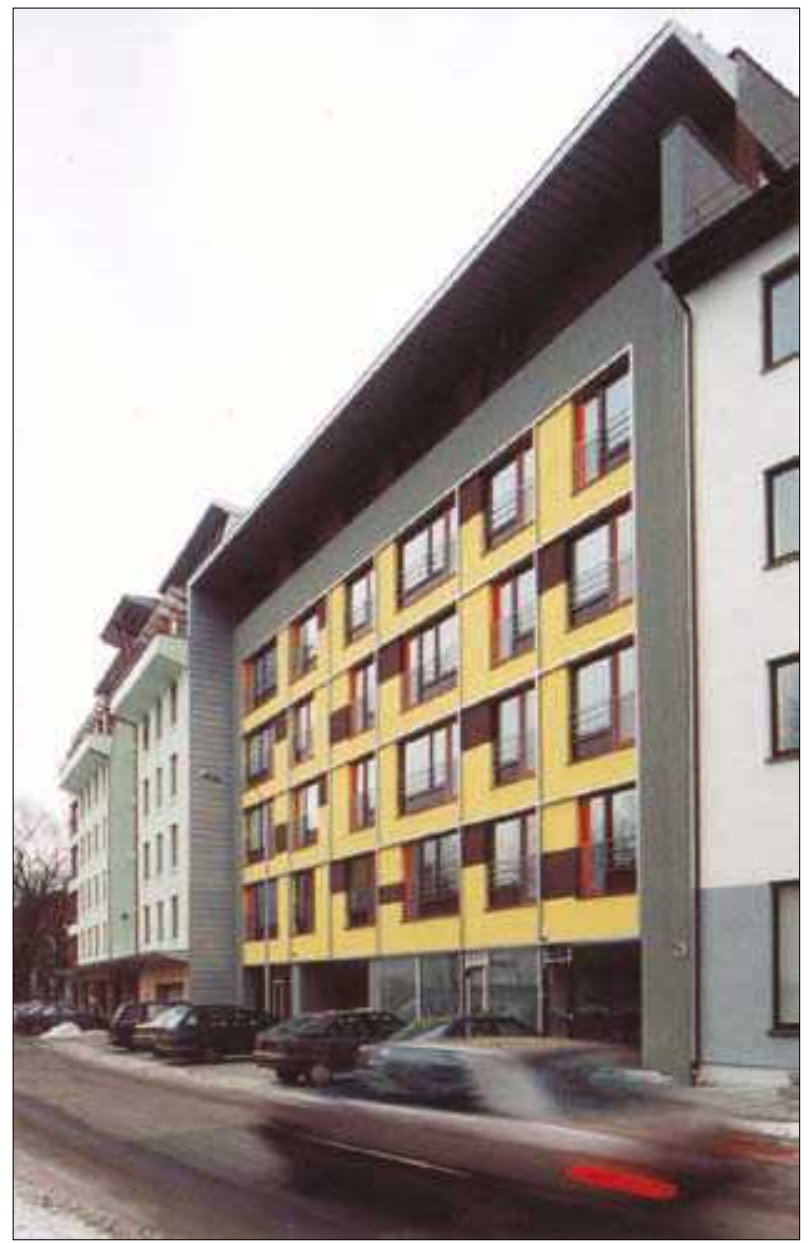

7 pav. Daugiabutis namas su įstaigomis Sierakausko g. (archit. G. Čaikauskas, R. Palekas)

Fig. 7. Block of flats with offices in Sierakauskas st. Arch. G. Čaikauskas, R. Palekas

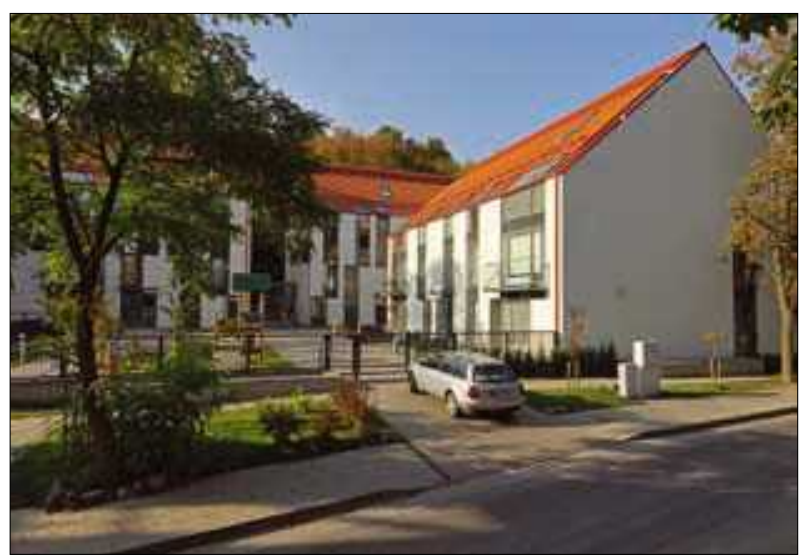

8 pav. Gyvenamasis kvartalas Krivių g. (archit. V. Balčiūnas, V. Biekša, M. Kanevičius)

Fig. 8. Blocks of flats in Kriviai st. Arch. V. Balčiūnas, V. Biekša, M. Kanevičius 


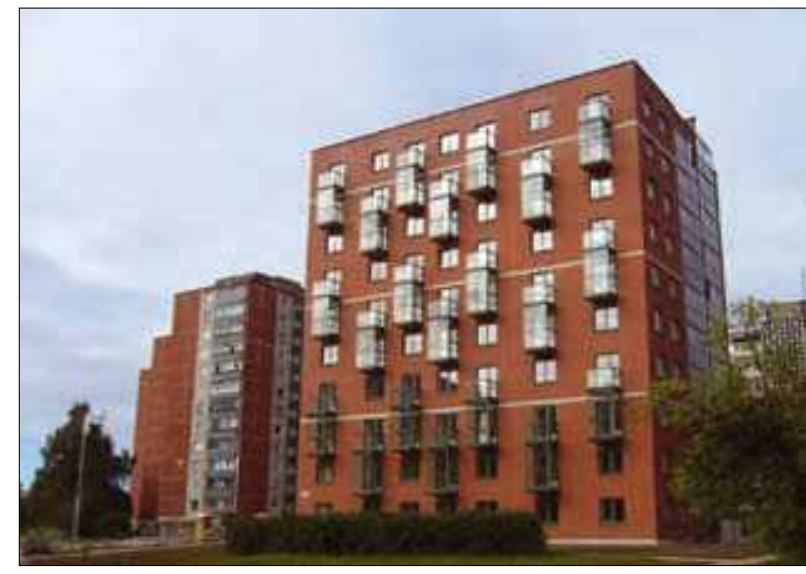

9 pav. Daugiabutis gyvenamasis namas L. Asanavičiūtės g. (archit. S. Dagelienè, S. Dagelis)

Fig. 9. Block of flats in L. Asanavičiūtè st. Arch. S. Dagelienè, S. Dagelis

nutartimis. Iškylanti pagrindinė socialinẻ problema (jeigu jau būna įvykdyti objektyvūs planavimo reikalavimai - išlaikyti reikalaujami atstumai, leistina tankumo norma, atlikti insoliacijos skaičiavimai ir pan.) yra naujų kaimynų atsiradimas šalia jau apgyvendintų pastatų. Neišvengiamas pasipriešinimas psichologine prasme yra suprantamas, nes naujos statybos visuomet reiškia būsimą diskomfortą: esančios laisvos erdvès sumažejimą, žaliųjų plotų nykimą, vizualinių ryšių su aplinka pasikeitimus, automobilių grūstis, galų gale statybos laikotarpiu galimą triukšmą, dulkes ir purvą. Kompromisą turètų padèti sukurti įsigaliojanti teisinès valstybès nuostatus atitinkanti tobulesnè teritoriju planavimo sistema, kuri privalètų objektyvizuoti ir suderinti visų šalių interesus.

Antra vertus, gamtoje veikiantis tuštumų užpildymo dèsnis pasireiškè ir urbanistikoje. Verslininkai pastebejo pokario miesto planavimo silpnąsias vietas, kitaip tariant, neracionaliai užstatytus žemės sklypus ir, pasinaudojus restitucijos ịstatymais, buvo suformuluotos prielaidos juos užstatyti. Tokios teritorijos buvo surandamos arti miesto centro, vertingiausiuose investiciju požiūriu kvartaluose, taigi verslo finansinis atsiperkamumas juose tapo realiai užtikrintas. Ši tendencija buvo tokia nauja ir neịprasta, kad miestas buvo jai visiškai nepasirengęs. Nesant jokių juridinių apsauginių svertų, tankinimo iniciatyva tapo itin sunkiai prognozuojama ir valdoma. Iškilus neatidèliotinai būtinybei reglamentuoti ịsibègejjusị procesą, savivaldybès įmonèje „Vilniaus planas" buvo parengta sklypų tankinimo metodika, kuri atitiko Vidurio Europos (ypač Vokietijos) susiklosčiusios aplinkos intesyvinimo principus ir patirtį. Šis rekomendacinio pobūdžio dokumentas iš dalies padejo

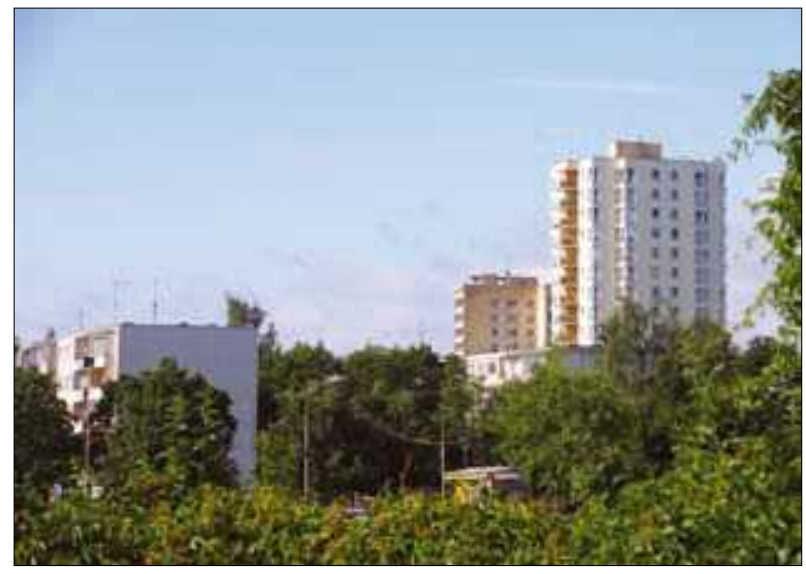

10 pav. Daugiabutis gyvenamasis namas Žirmūnuose (archit. V. Kormilcevas)

Fig. 10. Block of flats in Žirmūnai. Arch. V. Kormilcevas

išspręsti nemaža prieštaravimų, kurie nuolatos kildavo diskutuojant apie naujas statybas susiklosčiusioje aplinkoje. Tačiau dar liko neatsakyta i subjektyvius estetinius klausimus, kurie nepasiduoda jokiai objektyviai mokslinei interpretacijai. Tikrai nelengva surasti vienareikšmi atsakymą, kaip urbanizuoti suformuotas erdvines struktūras, kokio stiliaus naujieji pastatai turètų būti ir kaip juos derinti prie vyraujančios gyvenamųjų masyvų išraiškos. Pastaruoju metu išdygę tūriai, išskyrus retas išimtis, dažniausiai labai disonuoja su kontekstu, pasižymi individualia menine kalba. Šis miesto vystymo būdas sukuria dar daugiau sumaišties margoje, pastaruoju metu savavališkai rekonstruojamų pokarinių rajonų aplinkoje, juolab, kad tariamai nedideli be profesionalių projektų vykdomi pakeitimai (balkonų stiklinimas, langų keitimas, kondicionierių įrengimas ant fasadų ir pan.) i̇statymų apibrèžti kaip smulkus remontas, jie netgi nereguliuojami norminiais dokumentais ir nekontroliuojami statybos prižiūros instancijų. Miesto pastatų estetika nèra itteisinta kaip svarbus juridinis faktas, ji palikta kaip atsitiktinių sprendimų galimybè.

Šią gyvenamosios statybos koncepciją iliustruoja naujas pastatas Karoliniškèse ( 9 pav.). Autorių kūrybinèmis pastangomis daugiabutis meistriškai kontekstualiai priderintas prie gretimybių. „Atsižvelgiant ¡̣ siaučiantị statybų bumą, tokia erdvé jau susiformavusioje gyvenamųjų rajonų struktūroje tikrai negalèjo likti nepastebèta" (Čeburnis 2006). Žirmūnuose ir Antakalnyje, rajonuose, kuriuose neveikia paveldo apsaugos instancijų reikalavimai ir nèra susiklosčiusių tradicijų, tvirtų juridinių dokumentų, esminių planavimo nuostatų, pastatyti išsiskiriantys pavieniai daugiabučiai gyvenamieji namai - aukštybiniai akcentai Žirmūnų g. 


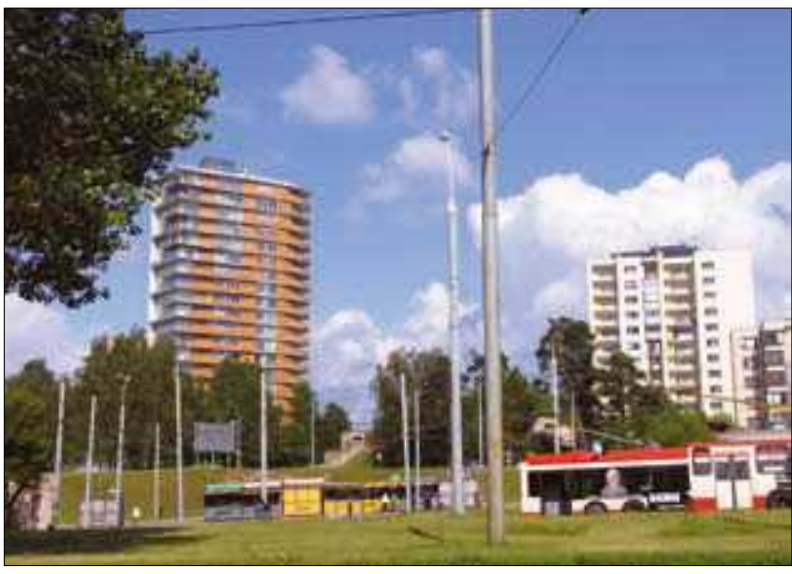

11 pav. Aukštybinis daugiabutis gyvenamasis namas Žirgo g. (UAB "Architektūros kūrybinè grupè")

Fig. 11. High-rise block of flats in Žirgas st. UAB „Architektūros kūrybinè grupè

(10 pav.), Žirgo g. Antakalnyje (11 pav.) ir daugiabutis šalia Žirmūnų prekybos centro (12 pav.). Šis projektas išsiskiria dar ir tuo, kad sudetingu, daugiapakopiu siluetu bandoma ieškoti realaus kompromiso ir glaudesnio dialogo su aplinkiniais senesniais pastatais.

\subsection{Daugiabučių gyvenamųjų namų statyba vietoj sovietmečio visuomeninių objektų}

Rinkos ekonomikos sąlygomis staiga padidejus žemès kainai, daugelio sklypų verte pranoko ant jų stovinčių sovietmečio visuomeninių pastatų materialiąją vertę. Taip susiformavo verslui patrauklios, tačiau išliekamosios meninès-kultūrinès vertès juridiškai neturintiems pastatams pražǔtingos kainų „žirklès“, kurios nulèmè kai kurių pokario objektų likimus. İdomūs sovietinio laikotarpio pavyzdžiai dèl santykinai trumpo egzistavimo laikotarpio nebuvo igije paminklinio statuso ir tapo lengviausiu taikiniu investuotojų, ieškančių naujų patrauklių ir juridiškai ịveikiamų žemės sklypų. Centrinese miesto teritorijose imta griauti privatizuotus visuomeninès paskirties objektus, o jų sklypuose atsirado prabangių daugiabučių gyvenamųju namų kompleksai. Vietoj buvusio nedidelio „Neries“ kino teatro iškilo aukštybinis daugiabutis gyvenamasis namas Antakalnio g. (13 pav.). Sveikatinimo kompleksą „Delfinas“ pakeitè daug diskusijų sukèlęs daugiabutis gyvenamasis kompleksas su komercinèmis patalpomis ir požeminiais garažais Juozapavičiaus g. (14 pav.), „Žalgirio“ plaukimo baseino sklype pastatyti „Mindaugo apartamentai“ (15 pav.). Didelis komercinių patalpų ir daugiabučiu gyvenamųjų namų kompleksas išaugo ant „Nidos“ banko liekanų (16 pav.). Vietoj sovietmečiu nebaigto statistikos valdybos

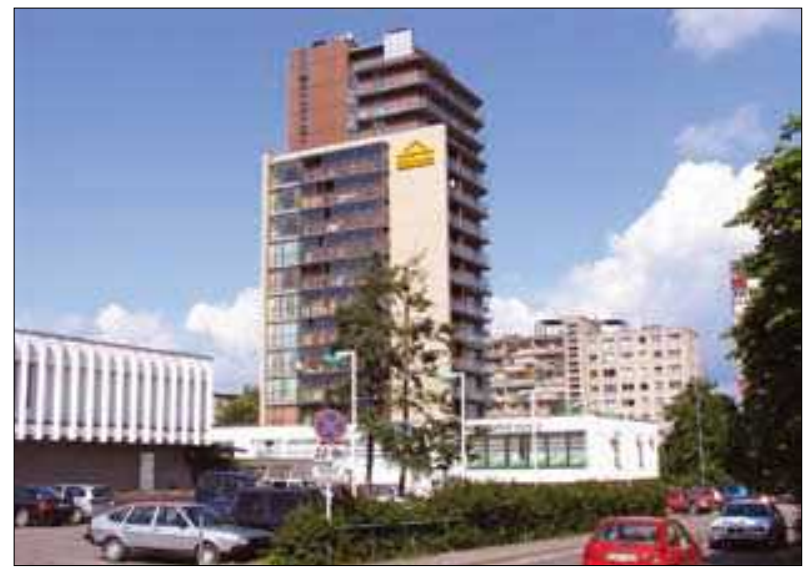

12 pav. Aukštybinis daugiabutis gyvenamasis namas Žirmūnu g. (archit. G. Balkè, D. Striukas, V. Stupak, E. Žarkovskienè, G. Tunaitis, L. Karmaza, V. Silevičius) Fig. 12. High-rise block of flats in Antakalnis st. Arch. G. Balkè, D. Striukas, V. Stupak, E. Žarkovskienè, G. Tunaitis, L. Karmaza, V. Silevičius

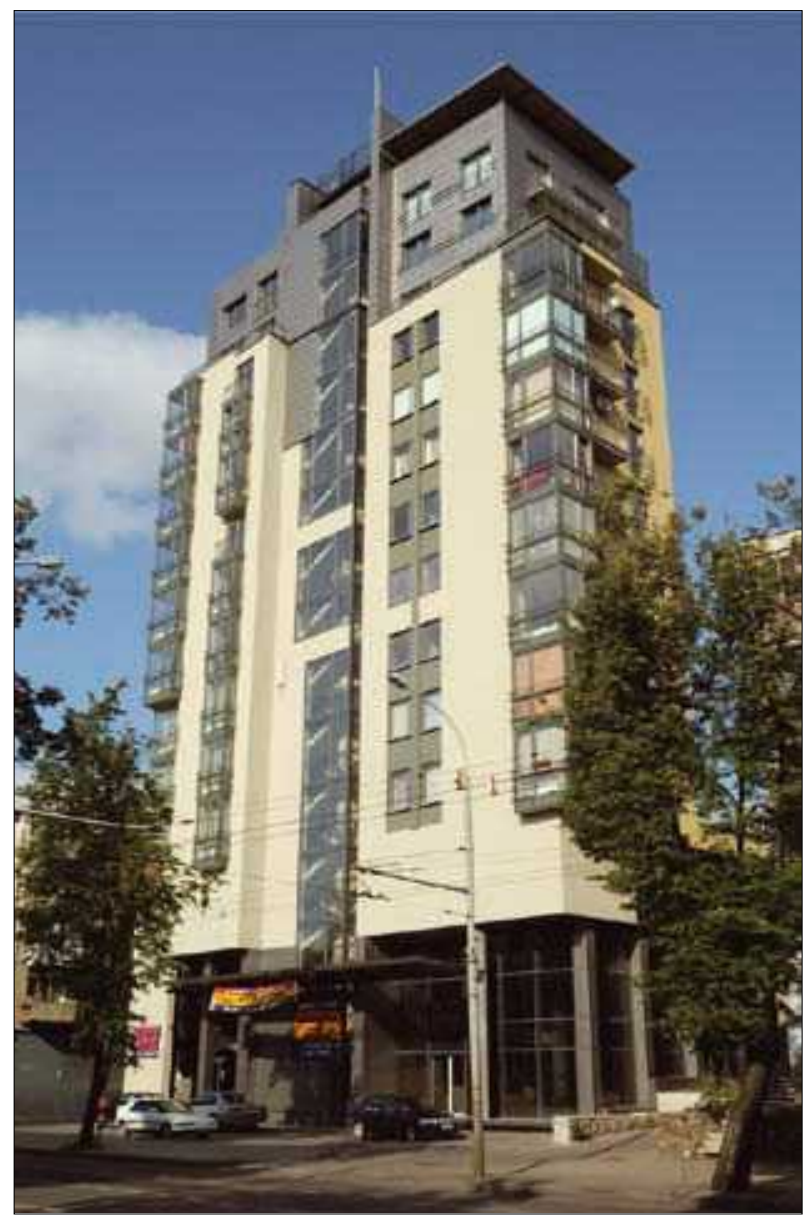

13 pav. Aukštybinis daugiabutis gyvenamasis namas Antakalnio g. (archit. L. Šarkinas)

Fig. 13. High-rise block of flats in Antakalnis st. Archit. L. Šarkinas 


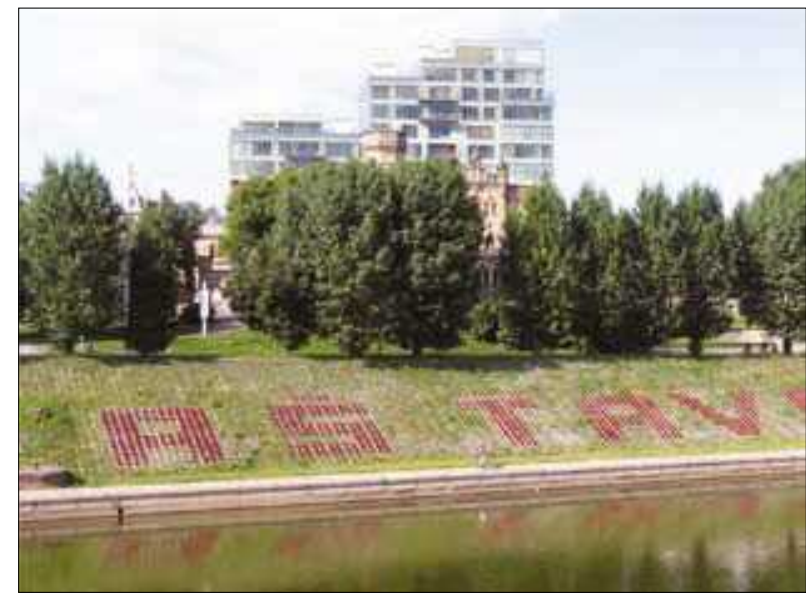

14 pav. Daugiabutis gyvenamasis kompleksas „Delfinas" su komercinèmis patalpomis ir požeminiais garažais Juozapavičiaus g. (archit. K. Pempè, L. Jančytė, E. Kirdulienè) Fig. 14. Complex "Delfinas" with blocks of flats, the commercial premises and parkings in Juozapavičius st. Arch. K. Pempè, L. Jančytè, E. Kirdulienè

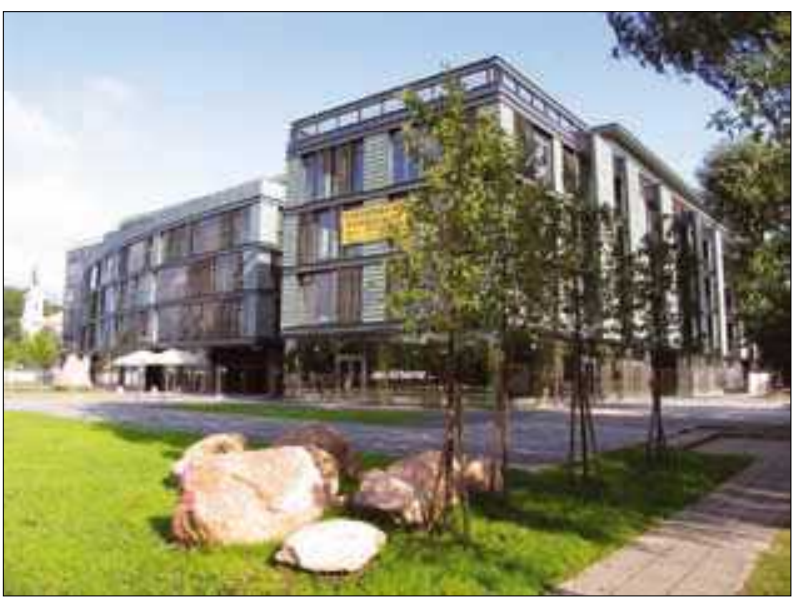

15 pav. „Mindaugo apartamentai“. Daugiabutis namas su įstaigomis Olimpiečių g. (archit. K. Pempè, R. Kirdulis, L. Jančytè)

Fig. 15. "Mindaugas apartments". Block of flats with offices in Olimpiečiai st. Arch. K. Pempė, R. Kirdulis, L. Jančytė

administracinio pastato (archit. G. Baravykas) ant požeminio transporto tunelio pastatytas ištisas daugiafunkcis kompleksas su gyvenamaisiais apartamentais „Vilniaus vartai“(17 pav.).

Procesas yra suprantamas ir palaikomas visuomenès, kai konvertuojamos buvusių kareivinių, pasenusios pramoninès ar kitos neadekvačios paskirties teritorijos, tačiau reakcijos, o kartais net ir didelio politinio pasipriešinimo susilaukia bandymai likviduoti unikalius architektūros objektus. Griovimo tendencija, ịgijusi didžiuli pagreitị, vos nenušlavė unikalaus Sporto rūmų

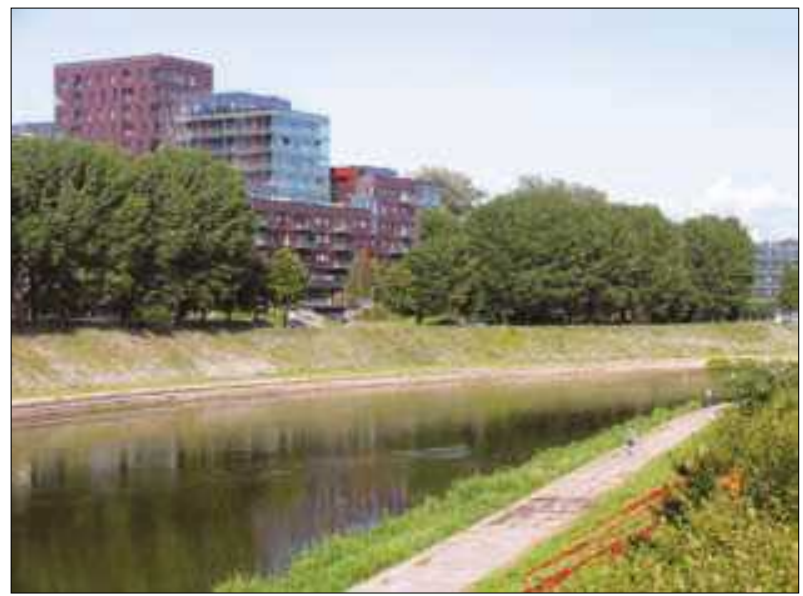

16 pav. Komercinių patalpų ir daugiabučių gyvenamuju namu kompleksas A. Juozapavičiaus g. (archit.

D. Pauliukonienè, A. Pliučas, M. Nagelè, E. Marcinkonis)

Fig. 16. Complex of the commercial premises and blocks of flats in A. Juozapavičius st. Arch. D. Pauliukonienè,

A. Pliučas, M. Nagelè, E. Marcinkonis

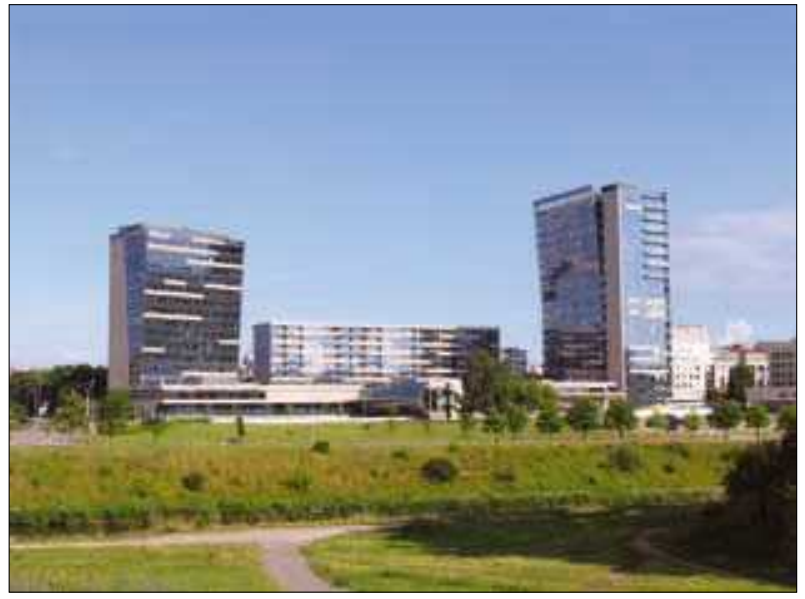

17 pav. Daugiafunkcis kompleksas su daugiabučiais "Vilniaus vartai", Tumèno g.

(UAB "Architektūros kūrybinè grupè")

Fig. 17. Multifunctional complex with blocks of flats "Vilniaus vartai" in Tuménas st.

UAB "Architektūros kūrybinè grupè"

pastato, kuris buvo apgintas ir ịtrauktas ị paminklų sąrašus tik altruistine Architektų sąjungos iniciatyva. Panašus klausimas yra sprendžiamas svarstant Centrinio telegrafo, „Lietuvos“ kino teatro ir kitų i̇domių, charakteringų pokario objektų likimus. „Verslas landžiai skverbiasi ne tik ị kokị tuštesnị miesto kampelį, bet ir i viešąsias erdves, o kartais net išstumia kultūrą, neatitinkančią to svarbiausiojo kriterijaus - pelningumo" (Leitanaitè 2005). Pastatai saugomi ir ginami kol kas tik visuomeninemis iniciatyvomis ir ịvairiomis akcijomis. Miesto gyventojų ir pavienių asmenų neabejingumas 


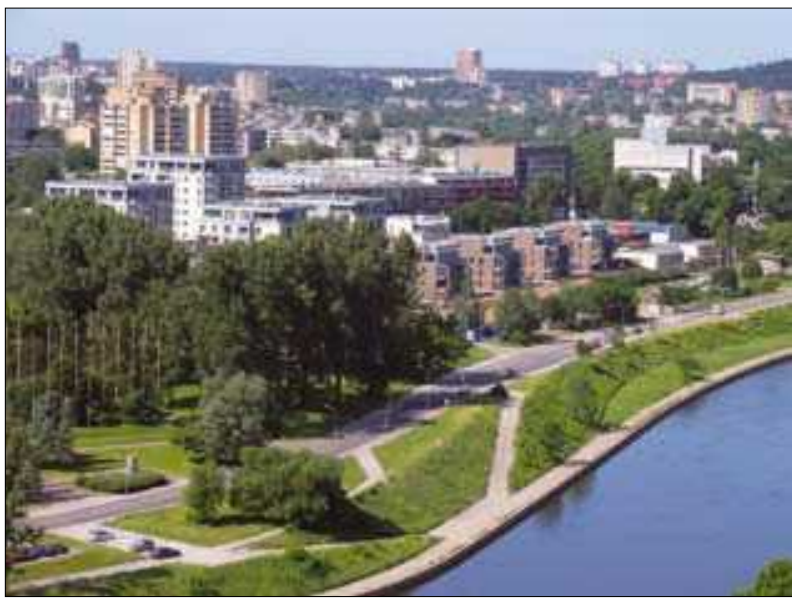

18 pav. Gyvenamasis kvartalas Raitininku g. (archit. G. Čaikauskas, V. Venckūnienè, J. Striukienè, P. Petkus)

Fig. 18. Blocks of flats in Raitininkai st.

Arch. G. Čaikauskas, V. Venckūnienè, J. Striukienè, P. Petkus

šioms problemoms liudija besiformuojančią pilietinę visuomenę, jos sąmonès brandą, nes „kiekvienas išnykęs objektas yra didelis praradimas ir neatkuriamas paveldo nuskurdinimas. Kiekviena šalis savo kultūros ir gamtos paveldo objektus privalo išsaugoti kaip žmonijos paveldo dalị. Pagal tai, kaip valstybė vertina, rūpinasi ir saugo kultūros paveldą, galima spręsti ir apie tos šalies kultūrą" (Glemža 2002).

\subsection{Naujų sklypų formavimas neužstatytose miesto teritorijose}

Intensyvi miesto plètra tebesitęsè ir nepriklausomybès laikotarpiu. Istorijos tèkmeje niekada neurbanizuotos teritorijos buvo užstatomos įvairios paskirties objektais. Dauguma šių statybų vyko jau atsižvelgiant ị parengtus miesto bendruosius planus, raidos programas. Patikslinus šiuos planavimo dokumentus detaliaisiais planais, buvo kuriami individualūs techniniai projektai ir pagal juos realizuojami ištisi nauji gyvenamieji masyvai. Centrinèje miesto dalyje, ịvertinus pasikeitusią miesto funkcinių zonų struktūrą, nuo monofunkcių teritorijų pereinant prie mišraus planavimo principų, atsisakius pletoti vien sporto ir pramogų funkcines teritorijas, jas perkèlus Šeškinès rajone buvusių laisvų teritorijų link ir priartinus jas prie potencialių lankytojų, buvo pastatytas gyvenamasis kvartalas Neries upès pakrantėje, Raitininkų g. (18 pav.). Architektai kompleksui, įsiterpusiam tarp Lietuvos tautinio olimpinio komiteto pastato, daugiabučių ir „Lietuvos ryto“ arenos, pabandè suteikti aukštesnę gyvenamosios aplinkos

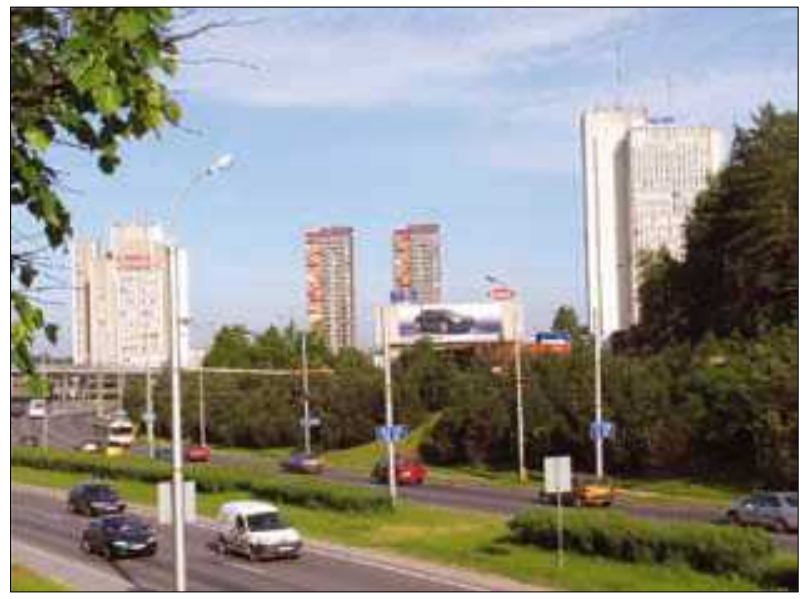

19 pav. Du aukštybiniai daugiabučiai pastatai Viršuliškių skg. (archit. G. Čaikauskas, M. Šejnicki)

Fig. 19. Two high-rise blocks of flats in Viršuliškès Alley. Arch. G. Čaikauskas, M. Šejnicki

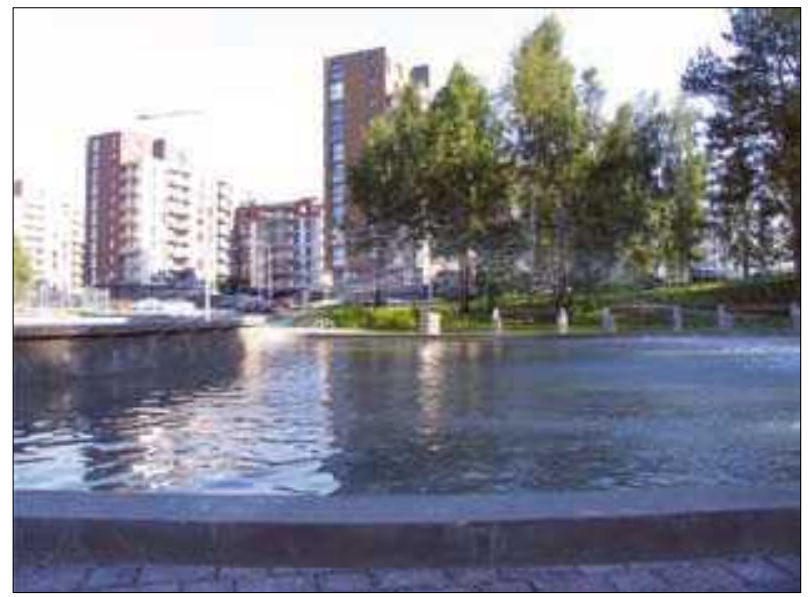

20 pav. Daugiabučių namų kvartalas „Bajorų kalvos“ Visoriuose (archit. G. Balkè, D. Striukas, E. Žarkovskis, G. Tunaitis, L. Karmaza, V. Silevičius)

Fig. 20. Blocks of flats "Bajory kalvos" in Visoriai. Arch. G. Balkè, D. Striukas, E. Žarkovskis, G. Tunaitis, L. Karmaza, V. Silevičius

kokybę ir sukurti ị miestovaizdị darniai ịsiterpiančią architektūrinę kompoziciją (Leitanaitè 2004).

Prieš keletą metų realiai pradètas vystyti antrasis, Vilniaus bendrajame plane numatytoje aukštybinių pastatų zonoje esantis naujas multifunkcis miesto centras su daugiabučiais gyvenamaisiais pastatais Viršuliškių skg. (19 pav.), statomas didelis gyvenamųjų namų kvartalas Visoriuose „Bajorų kalvos“ šalia sovietmečiu pradèto kurti Mokslininkų miestelio (20 pav.).

Toks miesto vystymas taip pat iš esmès atitinka natūralius laisvų teritorijų urbanizavimo dèsnius, tačiau nagrinėjamuoju laikotarpiu išryškèjo nepakankamai 


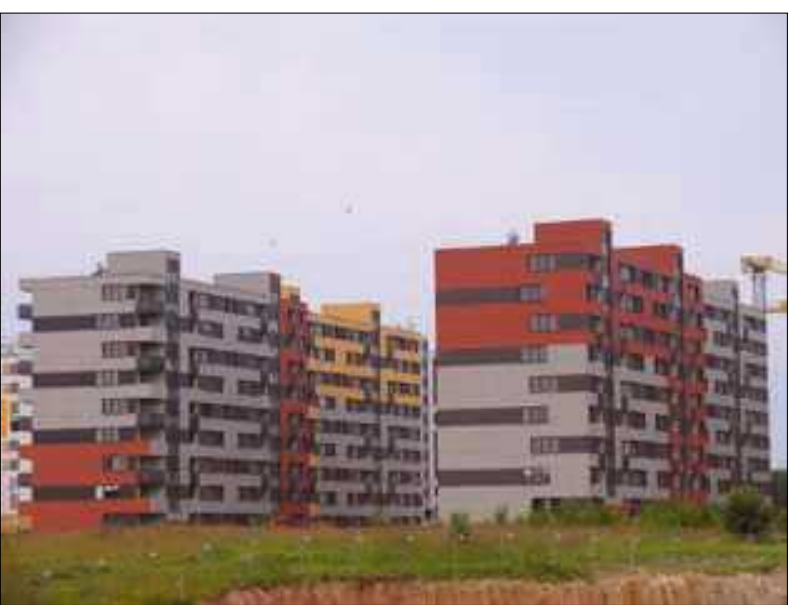

21 pav. Daugiabučių gyvenamujų namų kvartalas „Perkūnkiemis" (UAB „Architektūros kūrybinè grupè")

Fig. 21. Blocks of flats in "Perkūnkiemis" quarter.

UAB "Architektūros kūrybinè grupè"

brandžiai posovietinès ekonomikos sistemai būdingos socialinės problemos. Investuotojai, taupydamiprivačias lèšas ir siekdami didesnio pelno, vengè vystyti miesto infrastruktūrą ir statyti socialinès paskirties objektus šalia naujujų daugiabučių gyvenamųjų namų. Šios problemas visokiais būdais buvo atidètos vèlesniems laikams, tikintis palikti tai savivaldybei. Per visus Nepriklausomybès metus nebuvo pastatytas nè vienas vaikų darželis, nè viena bendrojolavinimo mokykla. Tik kai kur už privačias lěšas išplatintos ar nutiestos naujos gatvès. Naujųų daugiabučių gyvenamujų namų pirkèjai praktiškai iki šiol tebesinaudoja sovietmečiu arba dar anksčiau pastatytais vaiku darželiais ir mokyklomis. Tik pastaraisiais metas, pradejus statyti kvartalą „Perkūnkiemis“(21 pav.), imta reklamuoti būsimuju socialinių objektu statybą, tačiau iki šiol taip ir liko neaišku, kas ir kada juos finansuos ir kada jie iš tikrųjų bus pastatyti. Kol kas tik projektuose egzistuoja naujoji Balsių mokykla, skirta šiaurinių Vilniaus priemiesčių gyventojams.

Nors ir netrūko privačių investicijų gyventojų aptarnavimo sferai vystyti, tačiau didelių urbanistinių klaidu padaryta miesto planavimo srityje. Gigantiški prekybos centrai, stengiantis kuo arčiau juos priartinti prie potencialių pirkejjų, buvo statomi dažniausiai gretimuose sklypuose šalia gyvenamųjų kvartalų. Pasinaudojus nepakankamai darnia miesto plètros koncepcija ir netvirta valstybininkų politine valia, užimtos centrinès miesto kvartalu teritorijos, kurios iš esmès turejo būti skirtos daugiafunkciam miesto audiniui formuoti. „Daugiabučiai yra miesto architektūrinị audini formuojantys elementai. Mišrus ịvairių funkcijų, tiek gyvenamosios, tiek ir visuomeninès bei komercinès, ko-

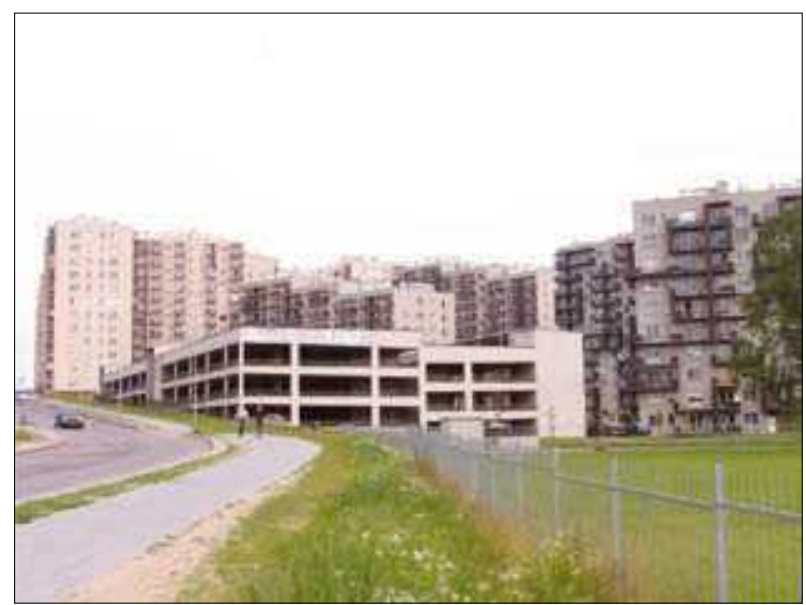

22 pav. Daugiabučių gyvenamujų namų kvartalas Fabijoniškèse, Ukmergès g. (archit. L. Grikinienè)

Fig. 22. Blocks of flats in Fabijoniškès, Ukmergè st. Arch. L. Grikinienè

egzistavimas daro lemiamą ịtaką daugiabučio sujungimui su esama miesto struktūra" (Gerdvilis 2007). Taigi modernios miestų urbanizmo idejos numato didesnius prekybos centrus su milžiniškomis atviromis automobilių aikštelèmis priemiesčiuose, tačiau Vilniuje ịvyko priešingai: komerciniai kompleksai, naujai pastatyti visiškai šalia centrinių miesto kvartalų, neracionaliai išnaudojo sklypų urbanistinį potencialą, užkirto kelią daugiafunkciškumo plètrai, sukūrẻ sunkiai ịveikiamas transporto problemas, savo žemais ir plokščiais tūriais ilgam laikui panaikino galimybę tose kvartalų dalyse sukurti i̇domesnị miesto siluetą.

Istatymų netobulumu ir reglamentuojančių reikalavimų stygiumi per nepriklausomos Respublikos planavimo sistemos brendimo metus jau spèjo iš dalies pasinaudoti apsukrūs verslininkai, speję nebrangiai ịsigytus grąžintos nuosavybès sklypus panaudoti intensyviam užstatymui ir pelningai parduoti gyvenamąji plotą pirkejjams iš dalies dar projektavimo stadijoje - vadinamuosius „virtualiuosius“ butus. Daug diskusijų ir prieštaringų vertinimų dèl investicijų lygio, statybos darbų kokybès, teritorijos ekologiškumo ir užstatymo tankumo susilaukè gyvenamasis kvartalas Fabijoniškèse, Ukmergès g. (22 pav.).

„Po 1990 metų Lietuvos daugiabučių rinkoje ryškèja tendencija, jog visuose namo projektavimo sąrangos lygmenyse - tiek horizontaliose namo projekcijose, tiek ir vertikaliame skerspjūvyje - naudojama skurdi funkcinè plano struktūros tipų ìvairovè. Butų funkcinès schemos neretai mažai kuo skiriasi nuo sovietmečio <...>. Dominuoja sekcijinio tipo plano struktūra"(Gerdvilis 2007). 


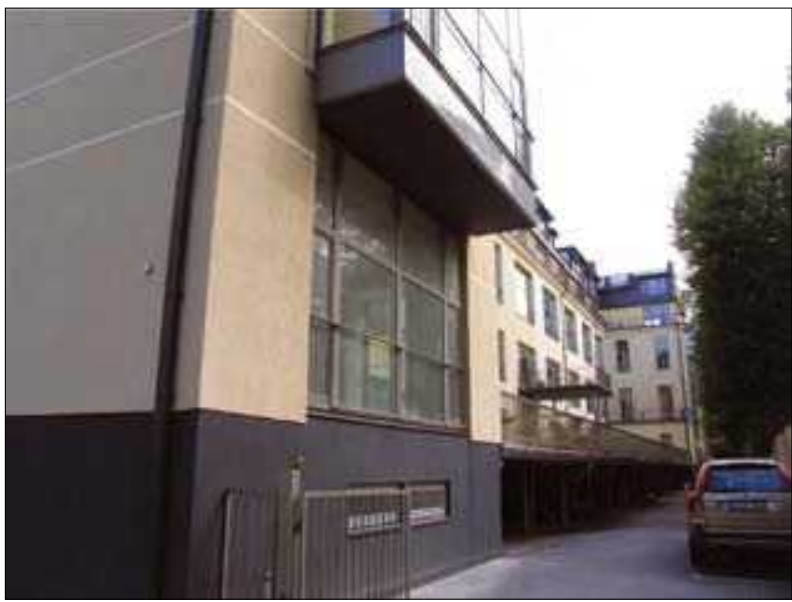

23 pav. Kazarmų konversija i daugiabuti gyvenamaji namą "Sapiegos dominija" Sapiegos g.

(E. Adomonio projektavimo firma)

Fig. 23. Cantonment conversion into block of flats

„Sapiegos dominija“ in Sapiega st. E. Adomonis Design Firm

\subsection{Daugiabučių namų statyba pramoninèse teritorijose}

Visame pasaulyje pramonès technologiju kaita atsispindi ir urbanistikos raidoje. Plečiantis miestų teritorijoms, didejjant investicijoms ir ieškant naujų plotų, naikinamos arba tolyn nuo miesto centro perkeliamos atgyvenusių gamybos technologiju immonès. Vèliau priklausomai nuo likusių pastatų architektūrinès vertès ir techninès būklès pramoniniai kompleksai arba konvertuojami, pritaikant juos naujoms paskirtims, arba paprasčiausiai nugriaunami. Technologinių pastatų tipologijos specifikai reikia savitų planavimo metodų, taip atsirado neịprastų gyvenamųjų butų, kurių patalpos gilios, todèl nepakankamai apšviestos („loftai“), kiti netradiciniai sprendimai. Kadangi sovietmečio industrinis palikimas yra itin skurdus ir menkavertis, tik nedaugelis šios srities pastatų realiai galètų būti išsaugoti pertvarkant juos ir pakeičiant jų paskirtį. Kaip parodè pastarųjų metų patirtis, jie, prieš statant daugiabučius gyvenamuosius namus, yra nugriaunami. Ryškiausias modernių „loftų“ realizacijos pavyzdys galètų būti caro laikų kazarmų, kurių patalpų gylis yra didelis, todèl jos sunkiai pritaikomas ịprastiniam gyvenamosios funkcijos sprendimui, konversija Antakalnyje, Sapiegos gatveje (23 pav.).

Iveikus didelį kritikų ir architektūrinès visuomenès pasipriešinimą, nugriovus pramoninio objekto - buvusios duonos kepyklos - dali, Vilniaus miesto bendrajame plane aukštybiniams pastatams nenumatytoje vietoje iškilo vertikalus akcentas Savanorių gatvès pradžioje (24 pav.). Jis itin pavojingai priartejo prie senamiesčio

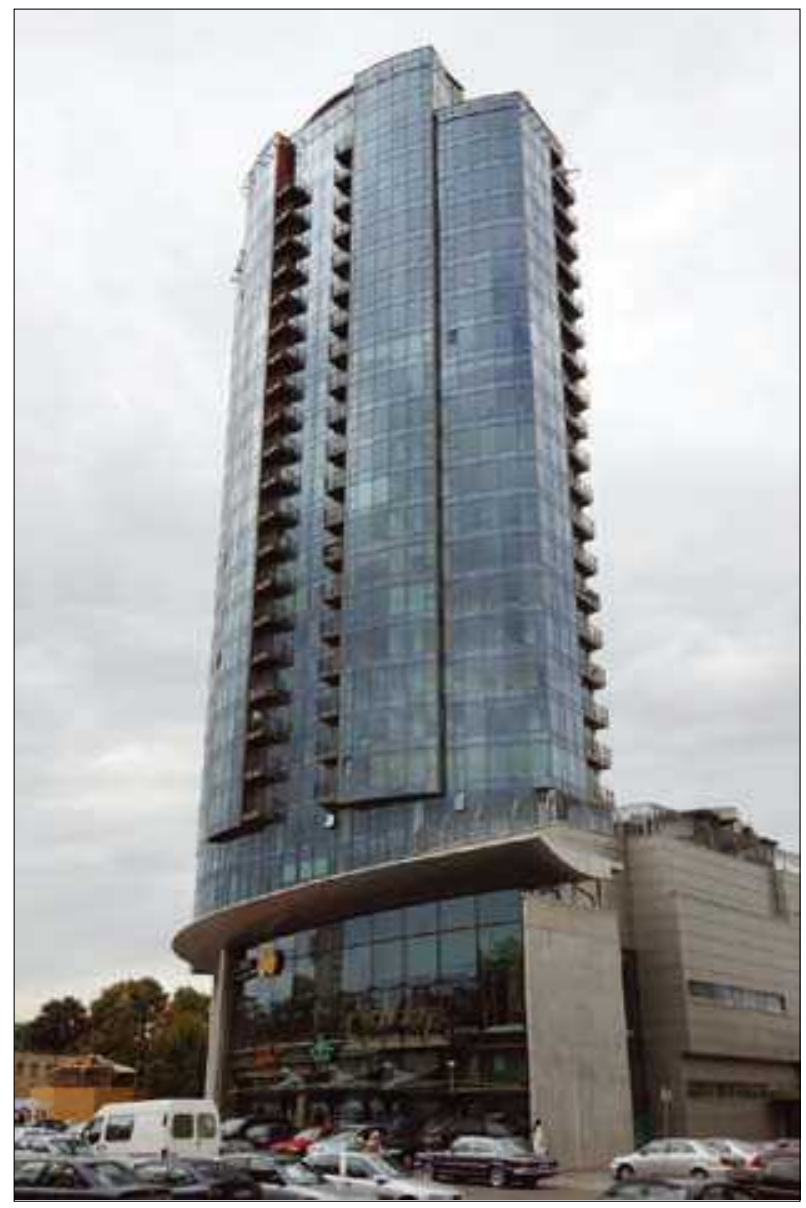

24 pav. Daugiafunkcis kompleksas su daugiabučiais Savanoriu pr. (archit. L. Merkinas)

Fig. 24. Multifunctional complex with blocks of flats on Savanoriai Avenue. Arch. L. Merkinas

panoramų, ir tai dar labiau paryškina vienišą jo siluetą, nes daugiau aukštybinių pastatų šioje vietoje buvo nutarta nebestatyti. „Lietuvos architektūrineje praktikoje kol kas gana retai pasiseka aukštybinị pastatą „ipiešti“ ị miesto audinị jautriai, be disharmonijos su kontekstu. Dažniausiai šiuolaikiniai bokštai išdygsta per arti istorinio centro ir stelbia jo trapaus mastelio vertikales ne tiek aukščiu, kiek masyviomis proporcijomis, dideliais tūriais"(Bružas 2004). Antrojo kompozicijos tūrio aukštis jau buvo apribotas vadovaujantis architektūros ekspertų tarybos protokoline nutartimi.

Labai aktyviai buvo konvertuojamos buvusios sovietinès armijos kareivinių vietos bei pramoninès teritorijos Šiaurès miestelyje K. Ladygos/J. Kubiliaus ir gretimose gatvėse (25 pav.), Aguonų, Kauno, Geležinio Vilko gatvių prieigose, kartu su kitos paskirties objektais rengiamasi statyti gyvenamuosius namus Užupyje veikusios elektros skaitiklių gamyklos "Skaiteks“ vietoje. 


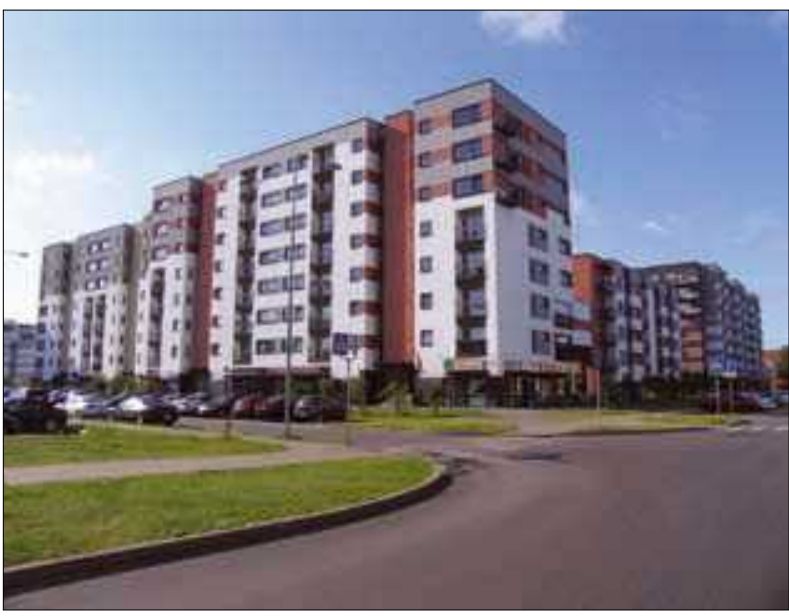

25 pav. Daugiabučių gyvenamujų namų kompleksas

K. Ladygos/ J. Kubiliaus g. (archit. A. Lèckienè, E. Kuprènienè, O. Vasilevskaja)

Fig. 25. Complex of blocks of flats in K. Ladyga/ J. Kubilius st. Arch. A. Lèckienè, E. Kuprènienė, O. Vasilevskaja

\section{Sovietmečio daugiabučių renovacija}

Naujas nuosavybès formų pasikeitimas pastaraisiais metais iškèlè dar didesnius susiklosčiusios sovietinio planavimo sistemos trūkumus, išryškino visuomenei nelauktas esamų gyvenamųjų kopleksų eksploatacijos problemas. Šiandien sprendžiami labai sudètingi pokario gyvenamųjų namų visuomeninès nuosavybès ir pastatų priežiūros klausimai, pradedant labai neapibrèžtais žemės sklypų ribų formavimo, likusių neracionalių tarpų (sklypų - „baltųjų miesto demių“) užpildymo ir baigiant sienų bei stogų šiluminès varžos nepakankamumo, nekokybiškų langų, durų pakeitimo galimybių paieškos klausimais. Dar daugiau - savavališkas vidaus planavimo tobulinimas, laikančiujų ir nelaikančiujjų sienų, pertvarų, gelžbetoninių plokščių ardymas arba savavališkas angų didinimas neturint legalizuotų projektų, atliekamas be specialistų konsultacijos ar priežiūros, neestetiškas ir atsitiktinis balkonų stiklinimas įvairiausiomis savininkams lengviausiai ìsigyjamomis pigiausiomis priemonèmis, fragmentiškas neracionalios, pasenusios inžinerinès įrangos keitimas pavieniuose butuose kelia didelių abejonių dèl šiu pastatų socialinio aktualumo, pagrịsto konstrukcijų ilgaamžiškumu ir eksploatavimo patikimumu, o kartu ir ilgalaikès finansinès investicijos prasme. Senieji, ikikariniai pastatai kasmet tampa vertingesni menine prasme, o jų kapitalinès konstrukcijos tobulinamos pritaikius moderniausias šiuolaikines technologijas, o pokario statybų daugiabučiu gyvenamųjų namų atnaujinimo klausimai visuomet neatsiejami nuo vis dar tebenagrinëjamų visiško nugriovimo versijų ir sunkiai

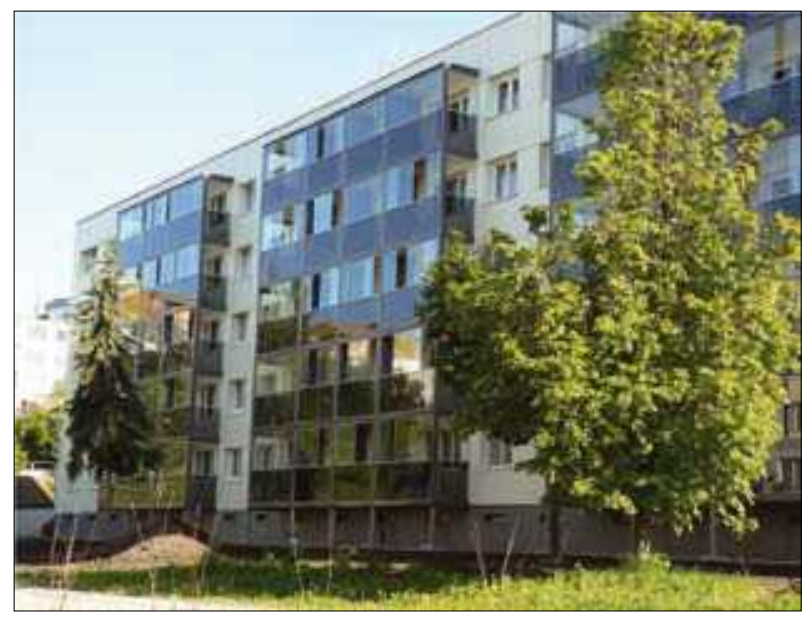

26 pav. Daugiabučio gyvenamojo namo renovacija Žirmūnu g. (archit. A. Bakanovas, S. Pamerneckis, D. Ruseckas) Fig. 26. Renovation of block of flats in Žirmūnai st. Arch. A. Bakanovas, S. Pamerneckis, D. Ruseckas

igyvendinamos rekonstrukcijos ar bent dalinès renovacijos sutelktomis valstybės ir gyventojų lěšomis. Ypač pavojingai skamba verslininkų keliamos idejjos, kad šiems pastatams reikia uždèti šlaitinius stogus, o, mansardose ịrengus komerciškai pelningas patalpas, jų sąskaita renovuoti šiuos pastatus. Toks sprendimas negrižtamai sudarkytų charakteringos funkcionalistinès stilistikos pokario gyvenamųjų masyvų architektūros bruožus. Buvusi valstybinè arba dar išlikusi kooperacinè nuosvybè, daugiabučių gyventojų iš seno susiformavęs įprotis nesirūpinti tuo, kas yra toliau jų buto durų, o dažnai ir finansinis senyvo amžiaus žmonių nepajègumas sukuria visuomenei labai sunkiai įveikiamas pastatų atnaujinimo problemas. Dar niekas iki šiol neakcentavo jų meninès vertès kaip vieno iš realaus išlikimo galimybių garantijų. Vargu ar greitai to sulauksime ateityje. Projektai, sukurti laikantis tik mokslo apskaičiuotų reikalavimų, nepaisant subjektyvių, bet neišvengiamai reikalingų meno dėsnių, vadovaujantis tik proto logika ir pigiausiais technologiniais sprendimais, neatsižvelgiant $\mathfrak{i}$ jausmus, vargu ar ịis rimtos meninès kategorijos statusą ir taps kultūros vertybèmis, visuomenei suprantamomis bei puoselèjamomis visais laikais. Visa viltis, kad objektyvūs nekilnojamojo turto išlikimo dèsniai sukurs šių objektų technines renovacijos prielaidas.

Antra vertus, turint aiškų tikslą ir nuosekliai jo siekiant galima realiai igyvendinti konkrečius rekonstrukcijos projektus, kurie ne tik iš esmès pagerina pastatų fizines savybes, bet ir tampa pakankamai moderniais ir estetiškais pavyzdžiais, demonstruojančiais vieną iš ga- 
limų šios problemos sprendimo būdų. Nors egzistuoja tik vienetai sėkmingai renovuotų sovietmečio daugiabučių gyvenamųjų namų, tai jau yra realūs ịrodymai, kad pasirinktas pakankamai perspektyvus kelias. Tai patvirtino kartotinio penkiaaukščio stambiaplokščio namo atnaujinimo pavyzdys Žirmūnų g. (26 pav.).

Atgavus Lietuvos valstybès nepriklausomybę, situacija daugiabučiu gyvenamųjų namų modernizavimo srityje iš esmès pakito, bet problemos neišnyko. Esamų būstų privatizavimo procesai tik dar labiau išryškino minètuosius trūkumus, asmenys, gyvenantys seniau statytuose butuose, dažnai yra visiškai nemokūs ir nepajègūs dalyvauti renovacijos procesuose. Apsukrūs verteivos, pusvelčiui supirkę tokių savininkų nuosavybę, juos pačius pavertè benamiais.

Prieš dešimtmečius pradèti statyti naujos kartos gyvenamieji pastatai sukūrè naujo požiūrio i̇gyvenamosios statybos plètrą idejją, tačiau ne visuomet tai pasiteisina realybeje. Ispūdingos statytojų reklaminès kampanijos teigè, kad tai itin modernūs, kokybiški būstai, tačiau ne vienas patiklus gyventojas po keleriu juose praleistu metų jau ėmè rimtai abejoti šiomis tiesomis. Pasirodè, kad dalis naujųjų pastatų yra dar prastesni už tuos, kurie buvo pastatyti sovietmečiu, ir netrukus teks juos taip pat renovuoti. Pradejo vyrauti nuomonè, kad pokario statyba yra nekokybiška, bet patikima ir laiko patikrinta, žmonès gerai žino šių objektų silpnąsias puses ir morališkai yra pasirengę jas taisyti. Naujieji pastatai, kurių konstrukcijos, siekiant privataus pelno interesų, formuojamos pačiomis taupiausiomis technologijomis, turi nemaža didelių trūkumų, kurie toli gražu neatitinka nustatytos kainos, nes tai jau tiesioginis verslo subjektas. Jau visi ėmè suvokti, kad vidinès kiemų erdvés, formuotos vadovaujantis visuomeninès žemès bendra nuosavybe (ar dar seniau - architektų intuicija) ir taip dažnai kritikuotos sovietmečiu, palyginti su naujai formuojamais kiemais privačioje žemejje, kur skaičiuojamas kiekvieno teritorijos kvadratinio metro atsiperkamumas, atrodo itin didelès. Labai rimta problema - automobilių stovejjimo vietų stygius. Saugyklų projektavimas ir jų igyvendinimas pastaruoju metu visiems statytojams taip pat yra nepatraukli tema. Šie objektai kainuoja daug, o gyventojai, ịpratę palikti savo automobilius gatveje ar tiesiog po savo ar kaimyno langu, labai nenoriai perka naująsias itin brangias aikšteles, taigi automobilių laikymo vietų stygiaus problema išlieka.

Esminis teigiamas rinkos bruožas yra savireguliacija, taigi nepriklausomai nuo asmeninių verslininkų norų situacija gyvenamųjų pastatų sferoje po truputi kinta ir gerèja. Atsiradus finansiškai pajègiems statybų rinkos dalyviams, kurių investicinès galimybès yra pa- remtos tarptautinių bankų investiciniais fondais, bet ne gyventojų avansiniais įnašais, prasidejo planavimo bei projektavimo procesas, kuris jau geriau atitinka šalies isstatyminę bazę. Atsiradusios šiuolaikinès statybos technologijos ir modernios medžiagos bei pakilusi darbo kultūra, susiformavusi investuotojų ir pirkèjų patirtis pradejo duoti kokybiškesnius rezultatus. Pastaruoju metu pastatyti gyvenamujjų namų kompleksai jau gerokai pranoko sovietmečio statinius, èmè lygiuotis ị tarptautinius standartus. Vis labiau prisotinta būsto rinka ir mažejanti statybų apimtis artimiausiu metu užtikrins kokybès augimą ir meninès vertès didejjimą, nes jau niekam nebereikès pirkti butų bet kuria kaina siekiant išvengti infliacijos ir turimų santaupų nuvertejjimo.

\section{Išvados}

1. Kiekvieno laikotarpio daugiabučių gyvenamųjų namų architektūros bruožai natūraliai atspindi visuomenès raidos dèsnius, kūrinių meninè vertè yra adekvati jos socialinei brandai.

2.Daugiabučių gyvenamųjų namų statybos tradicijų formavimuisi ir jų pritaikymui reliame gyvenime reikia ilgo laiko tarpo, aiškiai suformuotų turto nuosavybès santykių ir stabilios ekonominès raidos aplinkos.

3.Vien profesionalu - kūrèju pastangomis ar politiniais sprendimais neįmanoma pakeisti objektyviu daugiabučių gyvenamųjų namų kaip reikšmingos nekilnojamojo turto rinkos dalies meninès sampratos raidos dėsnių, tačiau jiems galima daryti įtaką ir juos valdyti, laipsniškai formuojant visuomenès sampratą apie architektūros meninès vertę ir pažangų socialini užsakymą.

4. Sovietmečio daugiabučių gyvenamųjų namų palikimą, sukūrus nuoseklią ir gerai organizuotą finansavimo sistemą, galima renovuoti ir pritaikyti moderniems šių dienų poreikiams.

\section{Literatūra}

Archiforma 1: 22-24. ISSN 1392-4710.

Bružas, A. 2004. Dar vertikalesnis Vilnius, Statybu pilotas 8: 5.

Buivydas, R. 2006. Architektūra: pozityvai ir negatyvai. Vilnius: UAB „EX Arte“. 163 p. ISBN 9955-9791-3-5.

Čeburnis, T. 2006. Daugiabutis gyvenamasis namas L. Asanavičiūtès g. 36.

Gerdvilis, V. 2007. Šiuolaikinio gyvenamo būsto funkcinè struktūra Lietuvoje: daktaro disertacijos santrauka. Vilnius: Technika.

Glemža, J. R. 2002. Nekilnojamojo kultūros paveldo apsauga ir tvarkymas. Vilnius: Vilniaus dailès akademijos leidykla. 
Leitanaite, R. 2004. Prabanga ant Neries kranto. Baseino vietą užims komercinis ir apartamentų centras, Statybų pilotas 6:12.

Leitanaite, R. 2005. Tas saldus žodis „kompromisas“. „Lietuvos“ kino teatras ištirps naujame daugiabučių kvartale, Statybu pilotas 10: 9 .

Leitanaitè, R. 2006. Istorinių dialektų paieškos. Daugiabučių kvartalas Užupyje išgirdo kontekstą, Statybu pilotas 1:4-5.

Leitanaitè, R. 2007. Santūrus flirtas su upe. Daugiabučių kvartalas Vilniuje atsigręžè ị Nerị, Statybu pilotas 11: 6-7.

Markevičienè, J. Fasadiškumas ir istorizmas, Archiforma 1: 75-77. ISSN 1392-4710.

Naujokaitis, L. 2002. Miesto investicinè aplinka ir investicijos, Archiforma 1: 52-54. ISSN 1392-4710.

Navickiene, E. 2000. Daugiabutis gyvenamasis namas Z. Sierakausko gatveje, Archiforma 3: 50-51. ISSN 1392-4710.

Navickienè, E. 2004. Nauja architektūra Lietuvos didžiujų miestu istorineje aplinkoje 1950-2003 m. Vilnius: Technika.

Navickienè, E. 2006. Nauja architektūra istorinèje aplinkoje: kūrimo patirtis. Vilnius: Technika.

Riaubienè, E. 2001. Gyvenamieji pastatai Maironio gatveje, Archiforma 3: 103-108. ISSN 1392-4710.

Vanagas, J. 2003. Miesto teorija. Vilnius: Vilniaus dailès akademijos leidykla. $185 \mathrm{p}$.

\section{RESIDENTIAL HOUSING DEVELOPMENT IN VILNIUS OVER THE PERIOD OF LITHUANIAN INDEPENDENCE}

\section{G. Čaikauskas}

Abstract. The paper is dedicated to the residential housing development in Vilnius during the years of the Lithuanian independence. Interruption of the natural society development by the aggression of the soviet system has ruined the architectural and building traditions in the city. Economic nationalization and change of property ownership from private to state or public has made a big mess in the land and real estate ownership. On the other hand, many interesting public buildings, built in the soviet period, have lost their actuality and are intended to be sold to private investors. The market economy has money-based urban development rules, so survival of the soviet-period architecture is under a big question too with a great wish of new businessmen to change it into residential areas. New approach to the modern conception of residential architecture development is gradually turning into live reality in independed Lithuania. It will take some time while the new approach to of the architectural image will be turned into an additional price of real estate as an essential value.

Keywords: residential housing, economic model of investments, city infrastructure, legitimate base, local detailed plans, urbanization of free spaces, renovation and modernization of buildings.

\section{GINTARAS ČAIKAUSKAS}

Architect, Professor (2006), Faculty of Architecture, Vilnius Gediminas Technical University (VGTU), Pylimo g. 26/Trakug. 1/26, LT-01132 Vilnius, Lithuania.

E-mail: gintaras.caikauskas@architekturoslinija.lt

Probation in Finland and USA (1990-1991). Membership: member of Lithuanian Union of Architects (1988); member (1999), chairman (2002) of Experts Council of Architecture and Urbanism in Lithuanian Union of Architects. Honorary awards: Award of Lithuanian National Arts and Culture nominated by Lithuanian Union of Architects; Award of Lithuanian Ministry of Enviroment nominated by Lithuanian Union of Architects. Publications: author of 2 research papers and tens of publications in professional press. Projects: author of over 200 projects of architectural design. Research interests: theory and practice of architecture. 